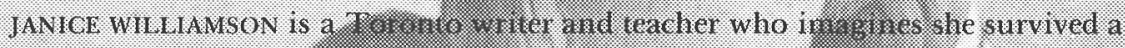

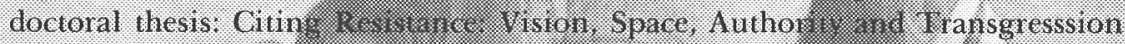

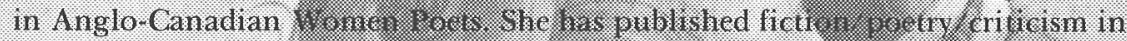

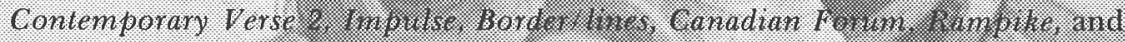

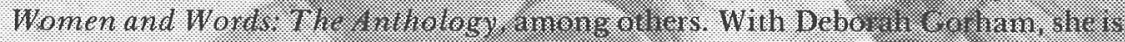

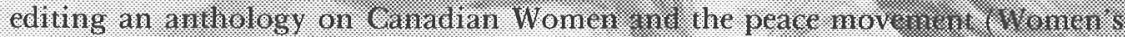
Press).

\title{
Tell-Tale Signs
}

IINTCR: WUI IAMSOR
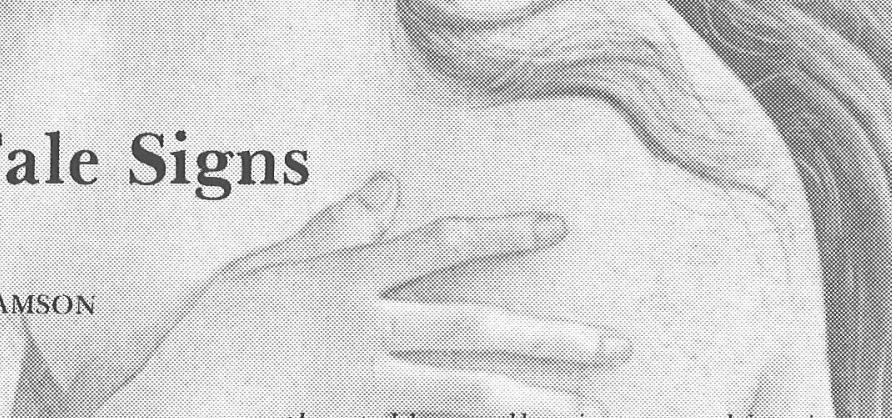

You 3.0 .10 so generous, they $10.1 \mathrm{~d}$ me, allowing everything in 1. place, but what we wanted to hear whe a story.

I. yn Hejinian:

1 here are signs that our speech is in circulation. Yet wo wite within, and alongside, a market with no exchange. She begins to adt. dience, "Are you listening?" Some reply derisively; others will : id . Her talk is a kind of restoration. with a twist. Well-worn clichés are lintodured. 1010. 100 Mt the narginal are juxtaposed to the exclusive cliques of the privilesed. Translation is difhicult. There is some talk of differehce Irom. Nervous laughter about "oppression", about the difference wilhin.

Or occasion, her voice trembles at the gap.

Stories begin to speak hemselves, are spoken twice, then agaln. Echo the others. From "Morher" Whllie Mae Ford Smith's enchanted songs to Emma Bovary's blackened tongure. Spoken wice, and then again. She gestures towards her listeners who begin with laboured breath. I0 speak.

Nothing will be gained by finishing the tale.

They will not "get it right". 
(The narrator poses questions

How many smiles? The prostitutes compare notes with the receptionists. How many upturned eyes? How many disinterested gestures of interest? Did you hear the one about the ad agency? Copy-writers test their best ideas on their expert secretaries. The girl at the front desk gets the biggest unofficial praise. In the ante-room, the elevator door opens and closes every four and a half minutes before her while she reads magazines non-stop except when answering the telephone at three-minute intervals. Sometimes models make an appearance through the mechanical hole in the wall. The doors slide soundlessly open. Framed in the cavernous vertical slit, the women rearrange their bodies, their minds. Anticipate the vacant stares. Occasionally, on cloudless days they wear see-through plastic raincoats. Nothing but luminescent breasts and palest skin. This costume creates a lasting impression. Helps her get a job. Outlines the contours of her "liberation".

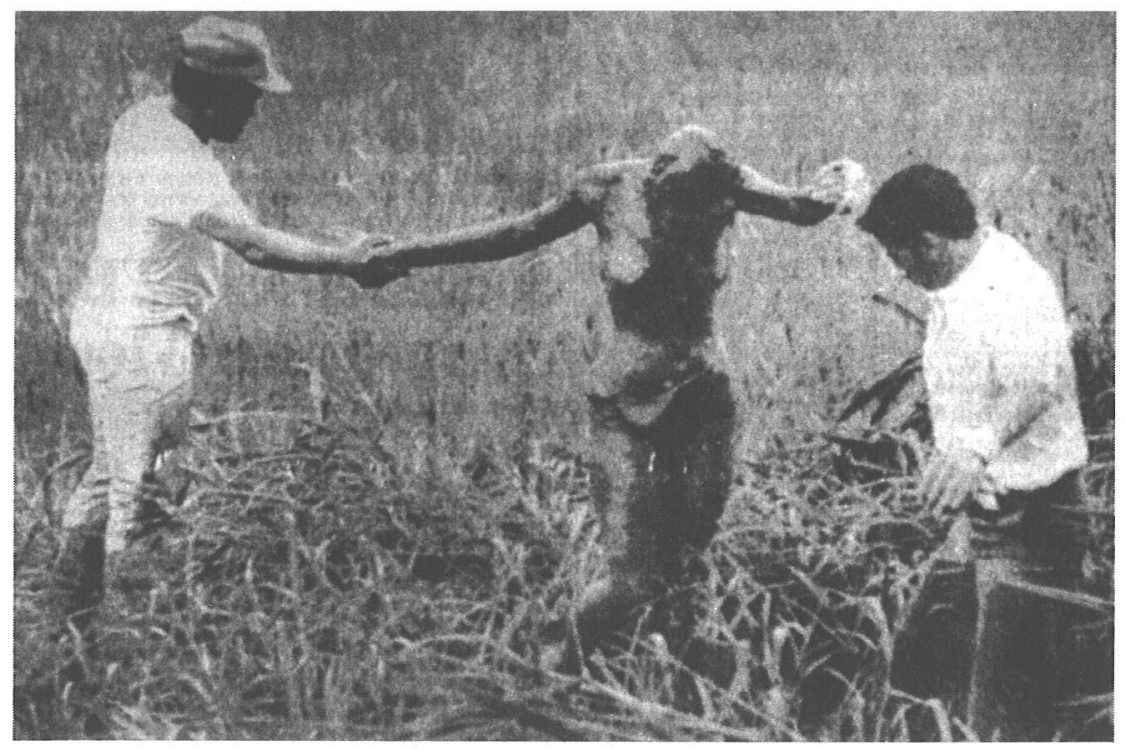

fig. 1

This is a photograph of two men and one woman. There is a disaster. This is an account of the event. The two men in fresh white face each other. Each grips an arm of the woman who is pulled to her feet, naked and covered in mud. Autocthonic, she is born in terror. 
(the narrator recounts her tale

When I was a young woman my children took hold of me at the station crying before I took the train to sing in the city. Hangin from my best suit they'd cry out momma momma then moan as the train come in. They'd cry out then moan when the train carried me away. Comin home soon I'd say cryin to no one.

One day papa calls me up says the children are cryin for you momma and you gotta come home. He says if you ain't on that Saturday train, I'm gonna come right down there and get you. Come early Saturday morning sure enough I get to that sweet station and there he is movin up that platform full o anger lookin to his feet not where he's headin and he's not lookin and I see him fall right down that elevator shaft. Crippled. Eight years he suffer from that fall.

So honey, you better convince your husband to get along with your children or grievous harm may come to him. Lord have mercy.

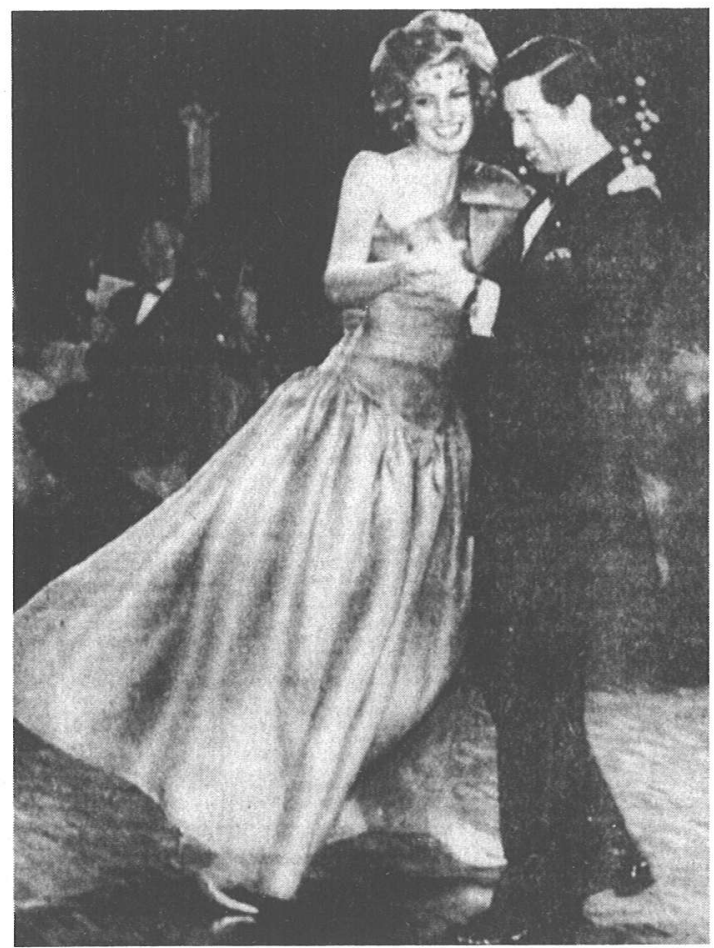

fig. 2

This is a photograph of a man and a woman. The tuxedo and off the shoulder ball gown gaze at each other without comment, charm the camera's eye. It is as though they were made for each other, for this three-day good will dance marathon from Australia to Washington. 
(the narrator adjusts her mask

"Emma tried to find out what one meant exactly in life by the words bliss, passion, ecstasy, that had seemed to her so beautiful in books." These explorations led her to empty pre-dawn rooms, through acrid corridors, along rain drenched paths. Rooting through catalogues and libraries she searched for clues to her dilemma. New friends dimmed lights taking her in turn to dance until all hollows disappeared.

Emma's head tilts toward a frame of drapery. The wheels of a cart's progress trundle in darkness. Her maid has lit candles, laid out silky petticoats and plump feather pillows. In the bath Emma tells her stories, peoples them with tender fingers and slippery beasts. Between chapters, her music swells, a repetitive suture of movements. She imagines the probing glass rods, the submarine flesh folded into itself. She can smell the taste, the sound caught, throated.

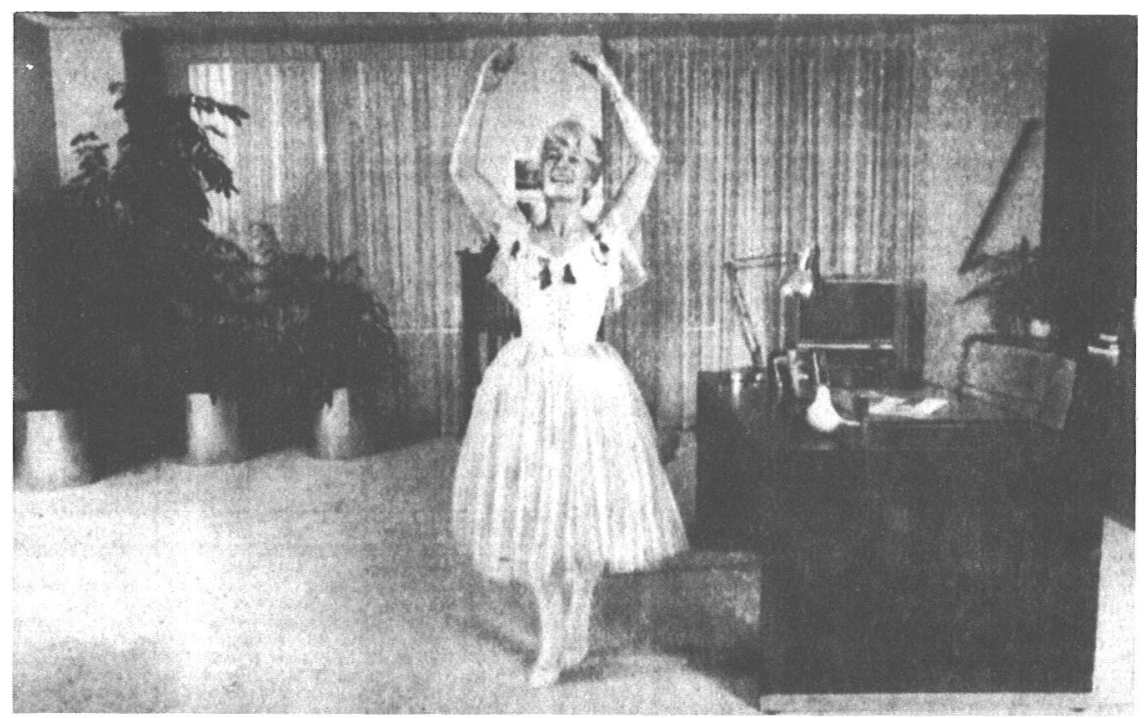

fig. 3

This is a photograph of a woman. The single figure is in disguise, not drag. This is obviously the case. At the side of an opulent desk a slim white woman awkward in a ballerina tutu pirouettes in a wood-panelled office. Tentatively she smiles as though growing accustomed to her position. 
(the reader's voice is infectious

No symptoms appear. There is nothing to treat; nothing to which one might surrender. When the blood appeared, it was to be expected. Fatigue does not plague her. Echoes, inside her chest are without significance. Measured responses, unremarkable. From inside her body, the gnawing is thought by others to be imagined. After a while she grows accustomed to pain's contours; the rhythms arch her back eloquently when watched.

Monitoring what ails her, a sequence of three tests are devised and named: "Emily 1", "Emily 2", and "Western Block". Her whole body is wrapped in plastic, then photographed. Her skin shines brilliant throughout. Even the spaces between her fingers cast shadows. The treatment takes place in a silent retreat. At first, the prognosis is good, though her progress slow. Then, contemplation infects her. There is a relapse.

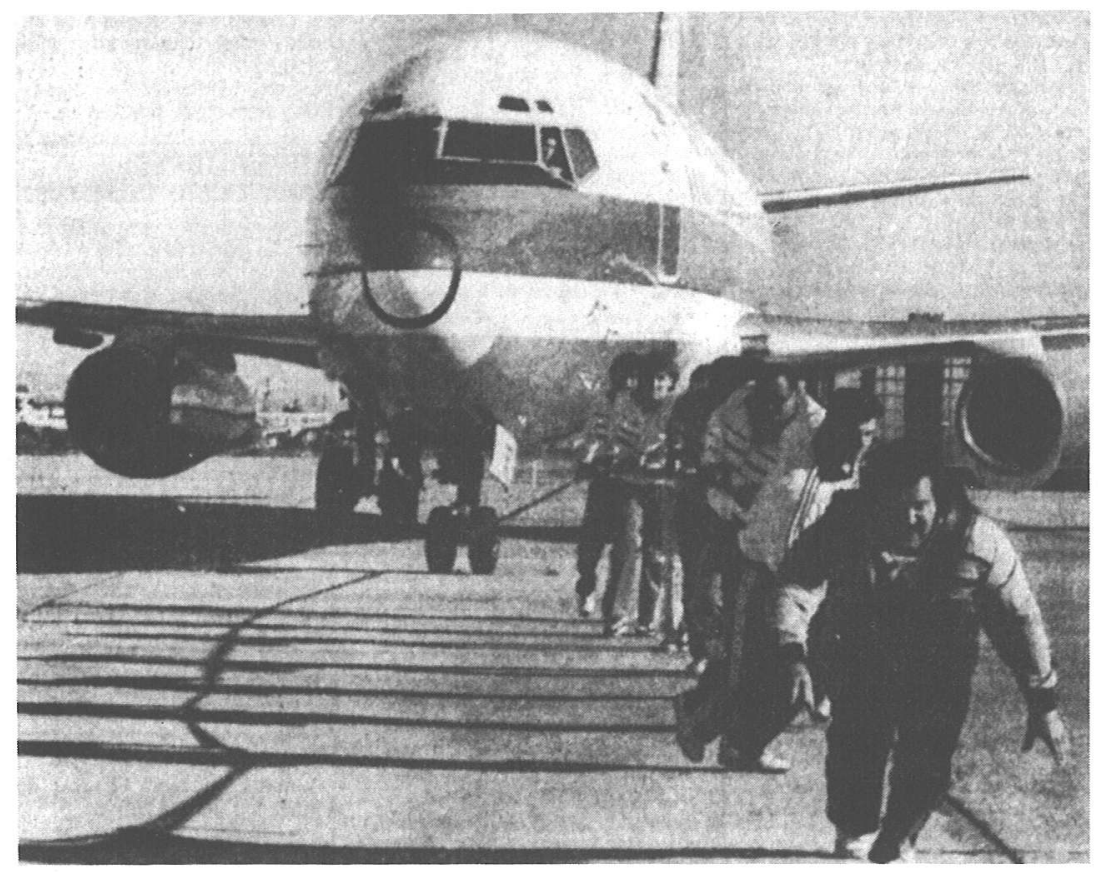

fig. 4

There is a photograph of the eight strongest men in the world. Ordered in a row their muscular arms pull at a rope at the end of which there is an airplane. Or something like a missile that flies ominously at night. The sweat appears like white flashes on their bodies. They move without fuel like magic down the runway. 
(The reader recovers her composure

Apples and cheese in a city perfumed between jasmine and frangipani. Others chew on dried biscuits delivered for breakfast and lunch. After dinner the atmosphere shifts from cocktails to machine-gun fire in the suburbs. The picture isn't pretty though the white sand beach remains. A tender ocean awaits.

Inland, the young white woman travels alone mistaken for doctor or princess, unskilled but not disinterested. Old men are brought to her, their eyes filled with dry wind, with blindness. Young girls and boys hide bloody wounds beneath their skirts, hide behind their mothers. The stranger bathes their wounds, dispenses gauze and good will. At dusk, the wife of the nomadic chief invites her to ride a cherished white stallion through the tented camp. She canters with a degree of grace. Her dress billows with the desert breeze, then whips about her flowing hair, revealing nakedness.

Dismounting, she is greeted by dignified applause. Onlookers present her with a zigzag silver ring, a tassled amulet secreting a scrap of the Koran, a one-eyed monkey, a lively duck, a wicker panier of dried meat, a tapestry of pictographs, a meal of rice and rancid butter, a carved wooden spoon. A white horse.

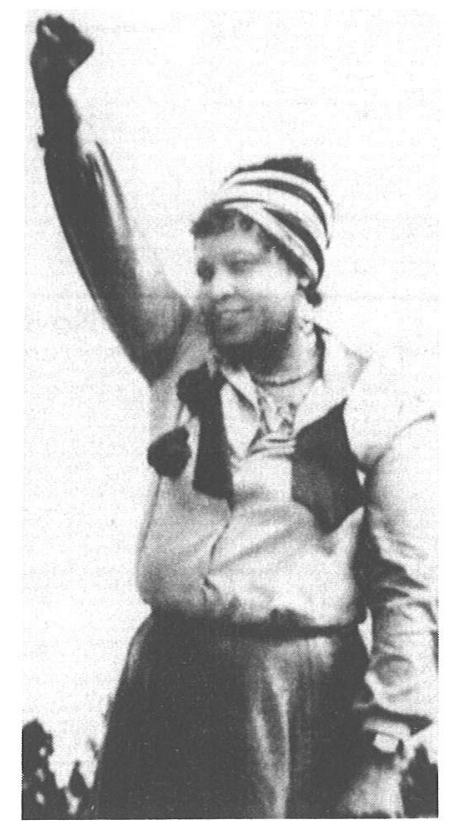

fig. 5

There is a photograph of a woman. The camera catches her from below where the others watch and listen. Her hair is tied round in fabric. She raises her black fist towards the upper left-hand corner of the image. Clear sky surrounds her. 